Universidad de Lima

Facultad de Derecho

Carrera de Derecho

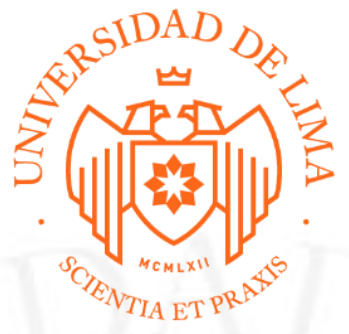

\title{
EXPEDIENTES CIVIL: "OTORGAMIENTO DE ESCRITURA PÚBLICA" Y CONSTITUCIONAL: "PROCESO CONSTITUCIONAL"
}

Trabajo de suficiencia profesional para optar el Título Profesional de Abogado

\author{
Vela Albornoz, Frank Carlos Antonio
}

Código 19972520

$$
\text { Lima - Perú }
$$

Mayo de 2019 
Materia: Otorgamiento de Escritura Pública.

$\mathrm{N}^{\circ}$ de Expediente: 24218-2010-0-1801-JR-CI-39

Vía procedimental: Proceso Sumarísimo

\section{RESUMEN}

El expediente trata de una demanda de otorgamiento de escritura pública que el accionante formula contra los demandados solicitando que cumplan con otorgarle una escritura pública de compraventa de un inmueble situado en el distrito de Villa El Salvador.

Materia: Proceso Constitucional de Amparo

$\mathrm{N}^{\circ}$ de Expediente: 09122-2010-0-1801-JR-CI-05 